ISSN 0103-8478

\title{
Parasitism and biological aspects of Tetrastichus howardi (Hymenoptera: Eulophidae) on Erinnyis ello (Lepidoptera: Sphingidae) pupae
}

\author{
Parasitismo e aspectos biológicos de Tetrastichus howardi (Hymenoptera: Eulophidae) em pupas de \\ Erinnyis ello (Lepidoptera: Sphingidae)
}

\section{Rogério Hidalgo Barbosa ${ }^{\mathrm{I}^{*}}$ Samir Oliveira Kassab ${ }^{\mathrm{I}}$ Fabricio Fagundes Pereira $^{\mathrm{I}, \mathrm{II}}$ Camila Rossoni $^{\mathrm{II}}$ Daniele Perassa Costa ${ }^{\mathrm{I}}$ Maykon Avalo Berndt ${ }^{\mathrm{II}}$ \\ - NOTE -}

ABSTRACT

Erinnyis ello is one of the main pests of the cassava crop, and its natural enemies including egg, caterpillar, and pupal parasitoids. The aim of this study was to evaluate parasitism and biological aspects of Tetrastichus howardi on $\boldsymbol{E}$. ello pupae. In general, parasitism and emergence of $\boldsymbol{T}$. howardi on E. ello pupae was $64 \%$. Cycle duration (egg to adult) of T. howardi on E. ello pupae was of $20.12 \pm 0.15$ days at $25 \pm 2{ }^{\circ} \mathrm{C}, 70 \pm 10 \%$ relative humidity, and 14-h photophase. The progeny of $\boldsymbol{T}$. howardi by $\boldsymbol{E}$. ello pupae was of $466 \pm 0.44$. Longevity of T. howardi females and males was of $15 \pm 0.57$ and $12 \pm 0.93$ days, respectively. The sex ratio was of $0.95 \pm 0.06$, and the ratio of females per female was $44 \pm 0.45$. T. howardi parasite and develops on E. ello pupae.

Key words: alternative host, biological control, cassava, pupal parasitoid.

RESUMO

Erinnyis ello é uma das principais pragas da cultura da mandioca e seus inimigos naturais incluem parasitoides de ovos, lagartas e pupas. O objetivo deste estudo foi avaliar o parasitismo e alguns aspectos biológicos de Tetrastichus howardi, criados em pupa de $\boldsymbol{E}$. ello. Em geral, o parasitismo e emergência de T. howardi em pupas de E. ello foram de 64\%. Duração do ciclo (ovo-adulto) de T. howardi em pupas de E. ello foi de 20,12 $\pm 0,15$ dias a $25 \pm 2{ }^{\circ} \mathrm{C}, 70 \pm 10 \%$ de umidade relativa e $14 \mathrm{~h}$ de fotofase.

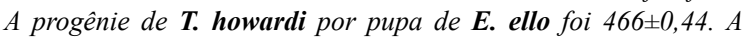

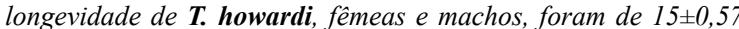

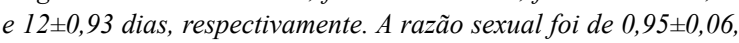
e a proporção de fêmeas por fêmea foi de 44士0,45. T. howardi parasita e se desenvolve em pupas de $\boldsymbol{E}$. ello.

Palavras-chave: hospedeiro alternativo, controle biológico, mandioca, parasitoide pupal.
Erinnyis ello (LINNAEUS, 1758) (Lepidoptera: Sphingidae), also known as "mandarová-da-mandioca" is one of the main pests of the cassava crop (AGUIAR et al., 2010). Caterpillars of $\boldsymbol{E}$. ello can cause $100 \%$ defoliation of plants and this reduces productivity of cassava crop (BARRIGOSSI et al., 2002). E. ello is mainly controlled by means of using chemical and biological insecticides. However, the hymenopteran parasitoids can be used to control this pest (MAFI \& OHBAYASHI, 2010).

Species of egg parasitoids were recorded on $\boldsymbol{E}$. ello, the most notable ones are Trichogramma atopovirilia (Oatman \& Platner, 1983), $\boldsymbol{T}$. MANICOBAI (BRUN, MORAES \& SOARES, 1984), T. marandobai (BRUN, MORAES \& SOARES, 1986), T. pretiosum (RILEY, 1879), and T. demoraesi (NAGARAJA, 1983) (Hymenoptera: Trichogrammatidae) (PARRA \& ZUCCHI, 1997), the parasitism of the last specie was recorded most frequently (RONCHI-TELES \& QUERINO, 2005).

Other studies reported the occurrence of parasitoids Cotesia sp., Euplectrus floryae (SCHAUFF, 2001) (Hymenoptera: Eulophidae) and Telenomus sp. parasitizing caterpillars and eggs of $\boldsymbol{E}$. ello, respectively (BELLOTTI et al., 2012; BELLON et al., 2013). Pupal parasitoids have potential to E. ello control, but published reports are scarce (BELLOTTI et al., 1992). Tetrastichus howardi (OLLIFF, 1893) (Hymenoptera: Eulophidae), endoparasitoids of the lepidopteran pests of agricultural crops, show great

IPrograma de Pós-graduação em Agronomia (Produção Vegetal), Universidade Federal de Grande Dourados (UFGD), Rodovia Dourados, Itahum, km 12, CP 583, 79804-970, Dourados, MS, Brasil. E-mail: hidalgo.rogerio@gmail.com.*Corresponding author.

IIPrograma de Pós-graduação em Entomologia e Conservação da Biodiversidade, UFGD, Dourados, MS, Brasil. 
potential as an effective biological control method (PRASAD et al., 2007).

The presence of the parasitoid T. howardi was recorded in the insect pupae of the families Crambidae, Noctuidae and Plutellidae (MOORE \& KFIR, 1995; CRUZ et al., 2011; VARGAS et al., 2011) and could be used to effectively control the lepidopteran pests. Thus, study the ability of T. howardi females to parasitize and develop on $\boldsymbol{E}$. ello pupae may contribute to the rearing of this natural enemy, as well as to generate opportunities for studying the potential of this parasitoid in controlling of $\boldsymbol{E}$. ello on cassava crop. The objective of the present study was report the parasitism and biological aspects of T. howardi on E. ello pupae, and this is the first record in Brazil.

In March 2012, in a commercial cassava plantation (cultivate 'Baianinha'), the outbreak of a lepidopteran defoliator was observed in the municipality of Angélica, MS, Brazil, which is located at $22^{\circ} 14^{\prime} 26^{\prime \prime} \mathrm{S}$ of latitude, $75^{\circ} 43^{\prime} 85^{\prime \prime} \mathrm{W}$ of longitude and $320 \mathrm{~m}$ of altitude. The affected area measured 40 ha. Plant spacing was $0.90 \mathrm{~m}$ between rows and $0.45 \mathrm{~m}$ between plants; the plants were 8-months-old.

A total of 127 insect's pupae were collected and sent to the Laboratory of Entomology and biological control (LECOBIOL) of the Faculdade of Ciências Agrárias (FCA), Universidade Federal of Grande Dourados (UFGD) in Dourados, Mato Grosso do Sul, Brazil. Ten specimens of the insect, including 5 males and 5 females, were sent to Prof. Dr. Marcelo Duarte (curator of the Lepidoptera Collection of the "Museu de Zoologia da Universidade de São Paulo") for identification.

A total of $100 \boldsymbol{E}$. ello pupae were used for mounting the bioassay. Fifty pupae of $\boldsymbol{E}$. ello pupae weighing between 3.397-3.807g were isolated in Petri dishes $(6.5-\mathrm{cm}$ diameter and $2.5-\mathrm{cm}$ high) with ten T. howardi females (48-hours-old, fed with pure honey drops) and parasitism was permitted for 24 hours. After which, T. howardi females were removed and the parasitized pupae were transferred to an acclimatized chamber at $25 \pm 2{ }^{\circ} \mathrm{C}$, with $70 \pm 10 \%$ relative air humidity and $14-\mathrm{h}$ photophase. Fifty pupae were used to calculated the natural mortality of E. ello pupae in the same conditions of the experiment to correct the mortality caused by the parasitoids.

The biological characteristics of $T$. howardi evaluated were: the percentage of parasitism [(the number of $\boldsymbol{E}$. ello pupae with parasitoid emergence + pupae without the emergence of $\boldsymbol{E}$. ello adults)/(total number of pupae) $\times 100$ ]; emergence of offspring [(the number of $\boldsymbol{E}$. ello pupae with adult parasitoid emergence)/(number of parasitized pupae) $\times 100]$, the duration of the cycle (egg-adult), number of parasitoid emergence per pupae (progeny), longevity, the sex ratio (number of females/number of adults) and ratio of females produced per females.

T. howardi (Figure 1A) parasite and develops on $\boldsymbol{E}$. ello pupae (Figure 1B) and the percentages of parasitism (Figure 1C) and emergence (Figure 1D) were 64\%. The duration of the cycle (egg-adult) of T. howardi on $\boldsymbol{E}$. ello pupae was of $20.12 \pm 0.15$ days. The progeny of $\boldsymbol{T}$. howardi on E. ello pupae was of $466 \pm 0.44$. The longevity of T. howardi females and males were $15 \pm 0.57$ and $12 \pm 0.93$ days, respectively. The sex ratio of parasitoid was of $0.95 \pm 0.064$, and ratio of females produced per females was of $44 \pm 0.45$.

T. howardi develops on $\boldsymbol{E}$. ello and this is important because it indicates that this parasitoid can be host for rearing of this parasitoid. However, $36 \%$ of the pupae used in the experiment were not parasitized by the natural enemy. The difference in the age of pupae used in the bioassay can be attributed to this result, because they were obtained from the field. Pupae of $\boldsymbol{E}$. ello parasitized by $\boldsymbol{T}$. howardi females were probably younger than those not-parasitized, because it was observed that this parasitoid prefers newly emerged pupae (MOORE \& KFIR, 1995; PRASAD et al., 2007; CRUZ et al., 2011). Parasitism obtained in this experiment can be increased if the natural enemy is reared for several generations on the E. ello pupae. The lowest variation on duration of the cycle (egg-adult) of $\boldsymbol{T}$. howardi on $\boldsymbol{E}$. ello indicates that host pupae are suitable for the development of this parasitoid. The period of development of this parasitoid on different hosts is variable, but generally, the cycle lasts from 14 to 20 days, as well as in this research. However, the variation in developmental period may be due to nutritional availability, the host immune response and size of pupa host, where the parasitoid was reared (FAVERO et al., 2013).

The longevity of males and females of $\boldsymbol{T}$. howardi was higher than that of other parasitoids, and therefore this natural enemy is advantageous for field conditions. It was observed that longevity of $\boldsymbol{T}$. howardi females is predominantly greater than that of other parasitoids of the genus Trichogramma sp. and Cotesia sp. (PARRA \& ZUCCHI, 1997; PARRA, 2002; BELLOTTI et al., 2012). This demonstrates that the parasitoid $\boldsymbol{T}$. howardi has more time to locate and parasitize the host in the field, which is an important advantage, because, in the field conditions, parasitism alone is sufficient to prevent the continued cycle of the pest. 


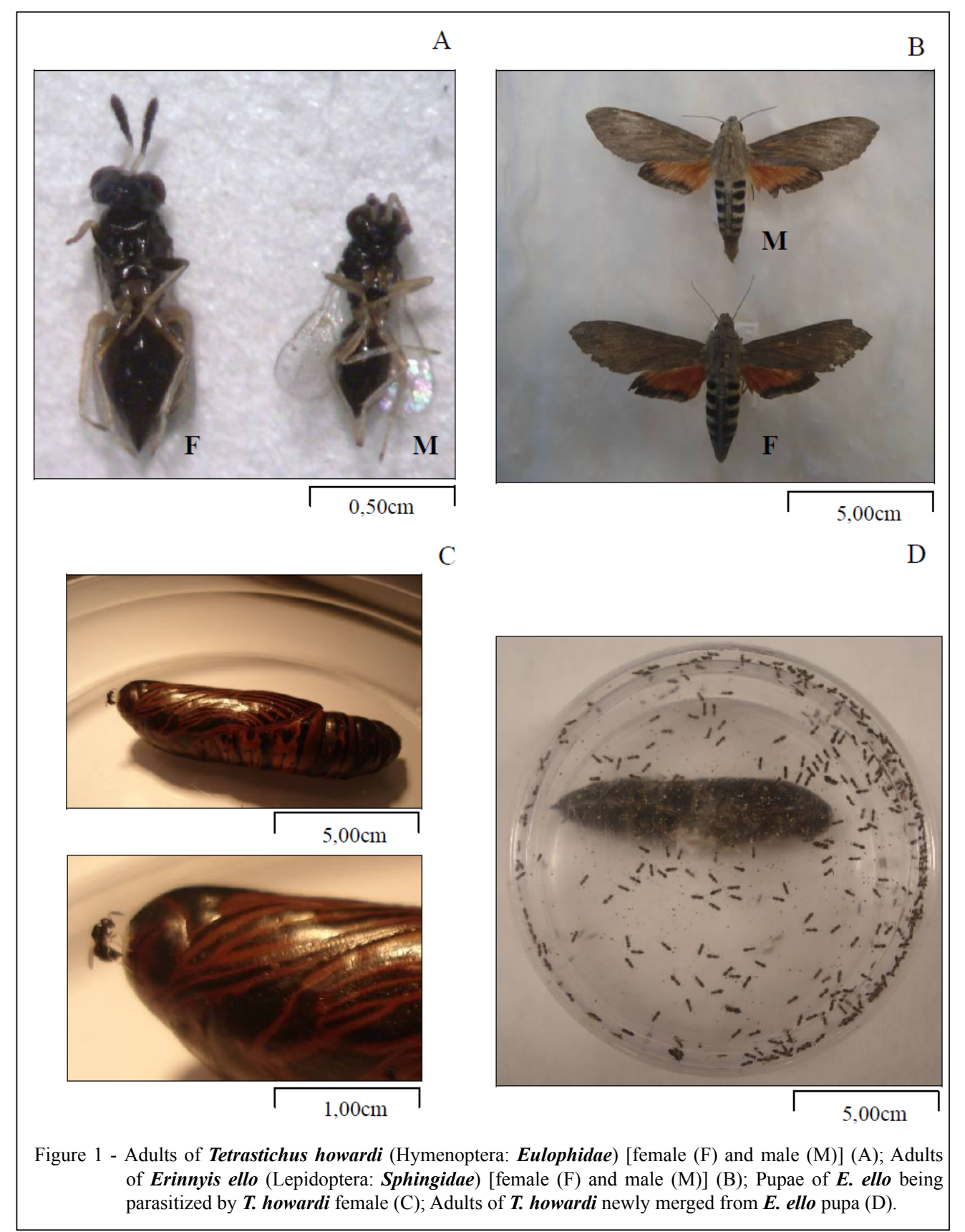

T. howardi can parasite and develop in $\boldsymbol{E}$. ello pupa and this is the first record in Brazil. However, the potential of $\boldsymbol{T}$. howardi to biological control of E. ello on cassava crop should be investigated and further relevant studies should be conducted.

\section{ACKNOWLEDGMENTS}

To Prof. Dr. Marcelo Duarte, Universidade de São Paulo (USP) for identification of $\boldsymbol{E}$. ello. The researchers are also grateful to the Conselho Nacional de Desenvolvimento Científico e Tecnológico (CNPq), Fundação de Apoio ao Desenvolvimento do Ensino, Ciência e Tecnologia do Estado de Mato Grosso do Sul (FUNDECT), Coordenação de Aperfeiçoamento de Pessoal de Nível Superior (CAPES) and to the biologist Paulo R. Barbosa de Souza.

\section{REFERENCES}

AGUIAR, E.B. et al. Monitoramento do mandarová da mandioca (Erinnyis ello L. 1758) para o controle com baculovirus (Baculovirus erinnyis). Revista Trópica, v.4, n.2, p.55-59, 2010. Available from: $<$ http://www.periodicoseletronicos.ufma.br/index. php/ccaatropica/article/view/ 157>. Accessed: Apr. 26, 2014. 
BARRIGOSSI, J.A.F. et al. Consumption rates and performance of Erinnyis ello L. on four cassava varieties. Neotropical Entomology, v.31, n.03, p.429-433, 2002. Available from: <http://www.scielo. br/scielo.php?pid=S1519-566X2002000300012\&script $=$ sci arttext>. Accessed: Jun. 25, 2013. doi: 10.1590/S1519566X2002000300012.

BELLON, P.P et al. de. First record of Euplectrus floryae (Hymenoptera: Eulophidae) parasitizing Erinnyis ello (Lepidoptera: Sphingidae) in Brazil. Revista Colombiana de Entomología, v.39, n.01, p.166-167, 2013. Available from: <http:// www.scielo.org.co/pdf/rcen/v39n1/v39n1a27.pdf $>$. Accessed: Apr. 26, 2014.

BELLOTTI, A. et al. Biological control of the cassava hornworm Erinnyis ello (Lepidoptera: Sphingidae). Florida Entomologist, v.75, n.04, p.506-514, 1992. Available from: <http://journals.fcla. edu/flaent/article/view/58885/56564>. Accessed: Jan. 25, 2013.

BELLOTTI, A. et al. Cassava production and pest management: present and potential threats in a changing environment. Tropical Plant Biology, v.05, p.39-72. 2012. Available from: <http:// link.springer.com/article/10.1007\%2Fs12042-011-9091-4\#>. Accessed: Feb. 22, 2013. doi: 10.1007/s12042-011-9091-4.

CRUZ, I. et al. New record of Tetrastichus howardi (Olliff) as a parasitoid of Diatraea saccharalis (Fabr.) on maize. Scientia Agricola, v.68, n.02, p.252-254, 2011. Available from: $\quad<$ http://www.scielo.br/scielo.php?script=sci_arttext\&pid $=$ S0103-90162011000200017>. Accessed: Apr. 23, 2014. doi: 10.1590/S0103-90162011000200017.

FAVERO, K. et al. Biological characteristics of Trichospilus diatraeae (Hymenoptera: Eulophidae) are influenced by the number of females exposed per pupa of Tenebrio molitor (Coleoptera: Tenebrionidae). Florida Entomologist, v.96, n.01, p.583-589, 2013. Available from:<http http://www.alice.cnptia. embrapa.br/handle/doc/970865>. Accessed: Apr. 23, 2014. doi: 10.1590/S0103-901620110002001928.

MAFI, S.; OHBAYASHI, N. Biology of Chrysocharis pentheus, an endoparasitoid wasp of the citrus leaf miner Phyllocnistis citrella
Stainton. Journal of Agricultural Science and Technology, v.12, n.02, p.145-154, 2010. Available from: <http://http://jast.modares. ac.ir/article_4361_926.html>. Accessed: Apr. 23, 2014.

MOORE, S.D.; KFIR, R. Aspects of the biology of the parasitoid, Tetrastichus howardi (Olliff) (Hymenoptera: Eulophidae). Journal of African Zoology, v.109, n.5, 455-466, 1995. Available from: $<$ http://agris.fao.org/agris-search/search.do?recordID=BE9600593>. Accessed: Feb. 23, 2013.

PARRA, J.R.P.; ZUCCHI, R.A. Trichogramma e o controle biológico aplicado. In: ZUCCHI, R.A.; MONTEIRO, R.C. (Eds.). O gênero Trichogramma na América do Sul. Piracicaba: FEALQ, 1997. V.1. 324 p. p.41-66.

PARRA, J.R.P. Controle biológico: criação massal de inimigos naturais. In: PARRA, J.R.P. et al. (Eds.). Controle biológico no Brasil: parasitóides e predadores. São Paulo: Manole, 2002. V.1. 626 p. p.143-161.

PRASAD, K.S. et al. Feasibility of mass production of Tetrastichus howardi (Olliff), a parasitoid of leaf roller (Diaphania pulverulentalis), on Musca domestica (L.). Indian Journal of Sericiculture, v.46, n.01, p.89-91, 2007. Available from: <http:// nldxb.njfu.edu.cn/en/oa/DArticle. aspx?type $=$ view $\&$ id $=20110$ 6026>. Accessed: Mar. 12, 2013. doi: 10.396910002006.2011.06.026.

RONCHI-TELES, B.; QUERINO, R.B. Registro de Trichogramma demoraesi Nagaraja (Hymenoptera: Trichogrammatidae) parasitando ovos de Erynnis ello (Lepidoptera: Sphingidae) na Amazônia Central. Neotropical Entomology, v.34, n.03, p.515-515, 2005. Available from: <http://www.scielo.br/ scielo.php?pid=S1519-566X2005000300023\&script $=$ sci arttext>. Accessed: Jun. 15, 2013. doi: 10.1590/S1519566X2005000300023.

VARGAS, E.L. etal. Record of Tetrastichus howardi (Hymenoptera: Eulophidae) parasitizing Diatraea sp. (Lepidoptera: Crambidae) in sugarcane crop in Brazil. Entomotropica, v.26, n.2, p.135-138, 2011. Available from: <http://www.entomotropica.org/index.php/ entomotropica /article/view/307>. Accessed: Apr. 26, 2014. 